技術報告

\title{
人工植物懪露装置を用いた $1,500{ }^{\circ} \mathrm{C}$ て発生をせた ガス状ホウ素化合物による各種植物への影響
}

鳥山成一 ${ }^{* 1} \cdot$ 水上昭弘 $* 2 \cdot$ 日吉真一郎 ${ }^{* 2} \cdot$ 山㟝敬久 ${ }^{* 2} \cdot$ 近藤隆之 ${ }^{* 2} \cdot$ 奥村秀一 ${ }^{* 2}$ 藤崎 進*2 . 溝口俊明*2 . 木戸瑞佳*2 . 中村篤博*2 . 安田 洋*3 . 中谷訓幸*4 田中 敦*5 $\cdot$ 西川雅高*5 $\cdot$ 吉永 淳*6 $\cdot$ 田尾博明*7

キーワード : ホウ素, 植物被害, ガス状ホウ素化合物, 人工曝露装置, クロマツ

\section{1.はじめに}

2001年，富山県内のある工場周辺において樹木 の葉が枯れる等の植物被害（アオキ, カキ, マツ 等27樹種）が発生し，工場風下 $250 \mathrm{~m}$ 程度まで影 響が見られた。そのため，急遽，植物被害現況調 査, 工場発生源・周辺環境調査, 樹木葉中のホウ 素濃度等調查の総合的な調査を行った。 ガス状ホ ウ素化合物による植物被害の報告例はなく，産業 廃棄物，土壤や河川水など，水系の污染に起因す る事例 ${ }^{1-6)}$ があるのみであった。

調査結果から, 原因物質が当該工場から排出さ れたガス状ホウ素化合物の可能性が高いとの結論 が得られ，工場に対しホウ素の排出抑制に関する 技術的な指導が行われ，環境の改善がなされた ${ }^{7}$. その後, 著者らはホウ素化合物発生装置（発生温 度 $\left.60^{\circ} \mathrm{C} \sim 90^{\circ} \mathrm{C}\right)^{8,9,12)}$ を作製し，ガス状ホウ素化合 物を人工植物曝露装置へ導入し, ゼラニウム ${ }^{8)}$ 及び各種植物 (野菜 7 種, 園芸植物 11 種, 樹木 7 種 ${ }^{12)}$ について植物被害の検証試験を行ったとこ ろ, 各種植物の葉の先端・周縁部に枯れが見られ 植物被害 ${ }^{8,12)}$ が再現された。しかしながら, 既報 ${ }^{8,12)}$
のホウ素ガス発生装置は, $60^{\circ} \mathrm{C} \sim 90^{\circ} \mathrm{C}$ での使用の ため，ホウ酸等の昇華によるホウ酸ガスである可 能性が高く, 問題の工場 $\left(1,500^{\circ} \mathrm{C}\right.$ 付近の操業) で発生しているホウ素化合物を全て網羅していな かった。

今回，小型電気炉を用いて不活性ガス雲囲気中 で酸化ホウ素を $1,500^{\circ} \mathrm{C}$ に加熱し，以前のように 電気炉を溶解させることなく，問題の工場とほぼ 同様の酸化ホウ素を主成分とした各種ガス状ホウ 素化合物 (酸化ホウ素, メ夕ホウ酸, ホウ酸)を発 生させることが可能な装置を開発した。 そこでこ の装置を用いて, 問題の工場とほぼ同様の各種ガ ス状ホウ素化合物を発生させ人工植物曝露装置へ 導入し, 植物被害の再現を試みた。また, 各種植物 への影響範囲や影響濃度を求めたので報告する.

\section{2. 調査及び測定方法}

\section{$2.11,500^{\circ} \mathrm{C}$ ホウ素化合物の発生装置及び人工植 物曝露装置}

当初, 問題の工場のような $1,500^{\circ} \mathrm{C}$ のホウ素化 合物発生装置の開発を試みたが，ホウ酸を用いて 加熱すると生成した酸化ホウ素が釉薬となって炉 材（アルミナ系, 炭素鋼系, 石英系）を溶融する ため， $500^{\circ} \mathrm{C}$ 以上に加熱できなかった，既報8, 9, 12)

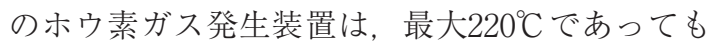

* 1 富山工業高等専門学校 Seiichi TORIYAMA

2006年12月25日受付

*2 富山県環境科学センター Akihiro MIZUKAMI, Shinichiro HIYOSHI, Takahisa YAMAZAKI 2007年 3 月 6 日受理 Takayuki KONDO, Hideichi OKUMURA, Susumu FUJISAKI, Toshiaki MIZOGUCHI,

Mizuka KIDO, Tokuhiro NAKAMURA

* 3 富山県林業技術センター Hiroshi YASUDA

* 4 富山大学大学院 Noriyuki NAKATANI

* 5 (独) 国立環境研究所 Atsushi TANAKA, Masataka NISHIKAWA

*6 東京大学大学院 Jun YOSHINAGA

* 7 (独) 産業技術総合研究所 Hiroaki TAO 
$100^{\circ} \mathrm{C}$ 以上はさらさらのホウ酸が塊状 $(お$ そらく，メタホウ酸）になるため，60～ $90^{\circ} \mathrm{C}$ でしか使用できず，ホウ酸の昇華に よるホウ酸ガスの発生装置であった。問 題の工場は $1,500^{\circ} \mathrm{C}$ 付近で操業しており, 予想されるガス状ホウ素化合物は, 酸化 ホウ素を主成分とした各種ガス状ホウ素 化合物 (酸化ホウ素, メ夕ホウ酸, ホウ酸) を発生させている可能性が高く, 同一の ガス状ホウ素化合物で曝露試験を実施す る必要があった。今回, 小型縦型電気管 状炉(アドバンテック：特FUT752, ヒー ター（二酸化モリブデン製） Max $1,800^{\circ} \mathrm{C}$, 炉心管 (ハイアルミナ製) $\phi 60 \times$ 1,000mm）を用いて，白金ルツボ（50ml） に酸化ホウ素（鹿特級；関東化学）を入 れ別途あらかじめ溶融させ，不活性ガス 雲囲気（本実験では窒素ガス使用）中で $1,500^{\circ} \mathrm{C}$ に加熱し, 各種ガス状ホウ素化 合物を発生させることが可能な装置を国 立環境研究所が開発した。予想されるガ ス状ホウ素化合物は, 酸化ホウ素を主成 分とした酸化ホウ素, メタホウ酸及びホ ウ酸等の分子からなるホウ素化合物ガス である。そこで，この装置を既報8，12)の 人工植物曝露装置へ導入した。

また，問題の工場煙道での発生源排出 ガスのガス状ホウ素化合物のホウ素濃度 は, 被害発生時が最大で $5.5 \mathrm{mg} / \mathrm{m}^{3} て ゙$, 対策 後の最近は, 最大で $0.14 \mathrm{mg} / \mathrm{m}^{3}$ 程度に下 がり,植物被害の発生は見られていない。

図 1 に $1,5000^{\circ} \mathrm{C}$ ホウ素化合物発生装置, ホウ素化合物曝露室と未曝露室を示す. 既報8, 12) と同様の人工植物曝露装置を 2 基準備し， 1 基は $1,500^{\circ} \mathrm{C}$ ホウ素化合物 発生装置からホウ素化合物を導入するホ ウ素曝露系と，もう 1 基は外気の久導入するホウ 素未曝露系を使用した。 人工植物曝露装置 ${ }^{8}$ 12) $は$, 日本医化器械製作所製の人工気象装置 (JPH-300RDSCD)，内部空気循環方式を外部ガス導入方式 に改良し，曝露室を約 $1 / 2$ の $560 \times 670 \times 570 \mathrm{~mm}$ に縮 小, さらに内部ファンを取付け，空気を均質化し た。運転条件 ${ }^{8}$ 12) として，照度は7,800Lux，曝露
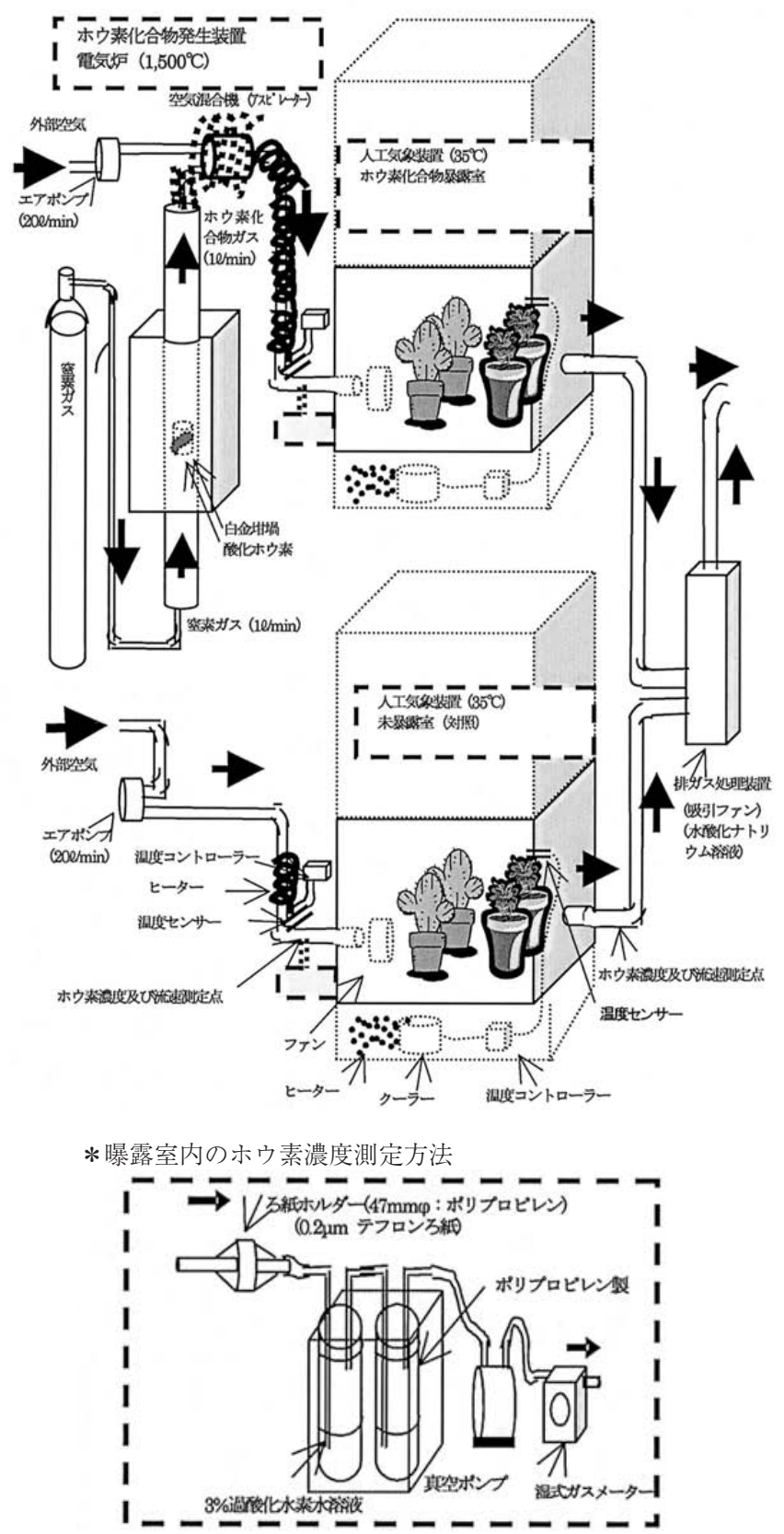

図 1 木ウ素化合物曝露室と末曝露室

室内温度は $35^{\circ} \mathrm{C} \pm 1{ }^{\circ} \mathrm{C}$ ，照明，温度等の基本サイ クルは，朝 9 時から夕方 17 時まで運転した。人工 植物曝露装置への導入ガス流速は，装置前後の測 定口で2.0土0.1m/secになるように流速を調整し， 人工気象装置の流入ガス量は $60 \pm 3 \ell / \mathrm{min}$ で流 入・排出されている。曝露後, 人工気象装置の排 出ガスは，2系統とも湿式排出ガス除外装置（水 
酸化ナトリウム噴霧)を経て大気中に放出させた.

また，曝露条件として，ガス状ホウ素化合物の みにするため, 対象の植物は鉢 $(10 \mathrm{~cm} \phi \sim 15 \mathrm{~cm} \phi)$ に入れ，鉢の土壤部分が曝露しないように茎の周 りをプラスチックフィルム（サランラップ）で覆 い，植物のみ曝露するようにした，植物への給水 は，ホウ素化合物が混入しないように，毎週（一 部，毎日)，鉢をプラスチック水槽に一晚浸す方 法で補給した。

曝露を終了させる判断は，既報8, 12) と同様，目 視で葉の約20\%に色の変化や枯れ等が見られた場 合とした。

\section{2 人工植物曝露装置導入ガスの木ウ素濃度測 定方法}

既報8,9１2）と同様のガス状ホウ素化合物捕集装 置を用いて導入ガスを捕集し， $0.2 \mu \mathrm{m}$ 孔径のテ フロンフィルターで粒子状物質を常温除去し, $3 \%$ 過酸化水素溶液 ${ }^{10)}$ の入ったポリプロピレン 製のバブラー付吸収瓶 2 連に吸収するようにし, 真空ポンプで毎分 $1 \ell$ 吸引捕集した。捕集後，ポ

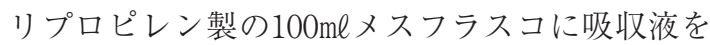
定容し，孔径 $0.2 \mu \mathrm{m}$ のディスポーサブルフィル ター（親水性テフロン）でろ過し, ICP 質量分析 装置（ICP-MS）（Hewlet Packard：HP-4500） でホウ素濃度を測定した。

導入ガスの濃度測定の頻度は毎日行い, ホウ素 曝露系の人工曝露装置内のガス状ホウ素化合濃度 は0.41 0.19mg $/ \mathrm{m}^{3} の$ 範囲で, 平均が $0.12 \mathrm{mg} / \mathrm{m}^{3} て ゙$ あった。これは被害発生時の煙道排出ガス濃度 $\left(5.5 \mathrm{mg} / \mathrm{m}^{3}\right)$ の約 $1 / 40$ に相当し, 被爆試験用環境 濃度としては十分ではないかと考えられる。

\section{3 各種植物の葉中の木ウ素濃度測定方法}

既報7,8,12) と同様，葉の表面の粒子状ホウ素の 沈着を除くために分析用の各種植物の葉を水洗浄 し水分をふき取った後, 既報7, 8) に図示したよう にホウ素曝露系は黄化・褐変部の先端・周縁部と 残りの中央部に扮拉まかに二分割した。ホウ素未 曝露系もホウ素曝露系とほぼ同様に二分割し，そ れぞれビーカーに入れ，乾燥機で $60^{\circ} \mathrm{C} ， 24$ 時間乾 燥させた。ただちに，メノウ乳鉢で粉砕し，ポリ ビンに保管した。

ポリビンに保管した粉砕試料を $0.050 \mathrm{~g}$ 秤量し, マイクロウェーブ分解容器に入れ, 硝酸 $8 \mathrm{ml}$ を加
え, マイクロウェーブ分解装置 (Milestone: ETHOS900, 分解温度 $\operatorname{Max} 90^{\circ} \mathrm{C}$ ）を用いて, 全

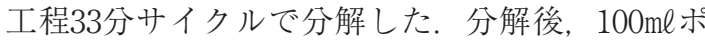
リプロピレン製のメスフラスコに定容し，口径 $0.2 \mu \mathrm{m}$ のディスポーサブルフィルター（親水性 テフロン）でろ過し， ICP - MS でホウ素の濃度 測定を行った。ポリビンに保管した粉砕試料の含 水率は, 秤量ビンで約 $0.050 \mathrm{~g}$ を精秤し, $110^{\circ} \mathrm{C} て ゙$ 1 時間乾燥し，恒量操作を行って求めた，植物葉 中のホウ素濃度は水分を補正し, 乾燥重量 $(\mu \mathrm{g})$

g）で表示した。

\section{4 分析操作及び個体間のバラツキ \\ 2.4.1 分析操作の精度}

ICP - MSの測定は, 測定毎に機器の精度チェッ クのチューニングレポートを作成し，内部標準物 質（コバルト）を自動添加し，イオンカウント值 の比（測定元素／内部標準物質）を用いて全て測 定した， 既法 ${ }^{9)}$ で検討した結果から，内標準元 素は水質環境基準の測定法 ${ }^{13)}$ でイットリウムを 用いてホウ素濃度を測定することになっている が，カリウム等のイオン成分の影響を受けるため コバルト $(59)^{13)}$ を使用した。

ホウ素濃度の変動係数 (別々の日の測定值 7 回) は, $1 \mathrm{ppb}$ 標準用液で変動係数0.054であった。 定量限界值は，有害大気污染物質測定マニュア ル ${ }^{14)}$ では，標準偏差の10倍 $(10 \sigma)$ の定量下限 值を推奨しており, 今回, 定量下限值 $(10 \sigma)$ が $0.49 \mathrm{ppb}$ であり，定量限界值は全て $1 \mathrm{ppb}$ を採用 した。

\section{4 .2 個体間のバラツキ}

表 1 にシロタエギク，チェイランサス，シロダ モについて, 各 $3 \sim 4$ 試料による人工植物曝露試 験の繰返し測定した結果を示す。シロタエギクの 曝露系の先端 - 周縁部, 中央部, 未曝露系の先端 · 周縁部，中央部のホウ素濃度の変動係数は0.07〜 0.32の範囲で，チェイランサスのホウ素濃度の変 動係数は0.04〜0.15の範囲で，シロダモのホウ素 濃度の变動係数は0.09〜0.20の範囲であった。

\section{3. 結果及び考察}

$1,500^{\circ} \mathrm{C}$ ホウ素化合物発生装置で発生した酸化 ホウ素を主成分としたガス状ホウ素化合物を人工 植物曝露装置に導入し, 各種野菜, 園芸植物及び 
表 1 個体間のバラツキ

\begin{tabular}{|c|c|c|c|c|c|c|c|c|c|c|c|c|c|}
\hline \multicolumn{2}{|c|}{ 名 称 } & \multicolumn{4}{|c|}{ シロタエギク } & \multicolumn{4}{|c|}{ チェイランサス } & \multicolumn{4}{|c|}{ シロダモ } \\
\hline \multirow{2}{*}{\multicolumn{2}{|c|}{$\begin{array}{ll}\text { 学 名 } \\
\text { 区 }\end{array}$}} & \multicolumn{4}{|c|}{ Centaurea cineraria } & \multicolumn{4}{|c|}{ Erysimum cheiri } & \multicolumn{4}{|c|}{ Neolitsea sericea } \\
\hline & & \multicolumn{2}{|c|}{ 未儤露 (対照) } & \multicolumn{2}{|c|}{ ホウ素嚗露 } & \multicolumn{2}{|c|}{ 末曝露 (刘照) } & \multicolumn{2}{|c|}{ ホウ素嚗露 } & \multicolumn{2}{|c|}{ 末曝露（対照) } & \multicolumn{2}{|c|}{ ホウ素曝露 } \\
\hline 葉の部分 & & 先端部 & 残部 & 先端部 & 残部 & 先端部 & 残部 & 先端部 & 残部 & 先端部 & 残部 & 先端部 & 残部 \\
\hline \multirow{4}{*}{$\begin{array}{c}\text { ホウ素 } \\
\text { 濃度 } \\
(\mu \mathrm{g} / \mathrm{g})\end{array}$} & 1 & 210 & 48 & 2700 & 1400 & 150 & 41 & 2400 & 350 & 160 & 40 & 1500 & 430 \\
\hline & 2 & 140 & 46 & 6400 & 2900 & 220 & 45 & 2800 & 360 & 110 & 37 & 1800 & 420 \\
\hline & 3 & 210 & 49 & 5200 & 1800 & 190 & 46 & 2400 & 330 & 150 & 53 & 1600 & 560 \\
\hline & 4 & 220 & 54 & 5400 & 2500 & 200 & 52 & & & & & & \\
\hline \multicolumn{2}{|c|}{ 平均值 } & 195 & 49 & 4925 & 2150 & 190 & 46 & 2533 & 347 & 140 & 43 & 1633 & 470 \\
\hline \multicolumn{2}{|c|}{ 最大值 } & 220 & 54 & 6400 & 2900 & 220 & 52 & 2800 & 360 & 160 & 53 & 1800 & 560 \\
\hline \multicolumn{2}{|c|}{ 最小值 } & 140 & 46 & 2700 & 1400 & 150 & 41 & 2400 & 330 & 110 & 37 & 1500 & 420 \\
\hline \multicolumn{2}{|c|}{ 分 散 } & 1367 & 12 & 2475833 & 456667 & 867 & 21 & 53333 & 233 & 700 & 72 & 23333 & 6100 \\
\hline \multicolumn{2}{|c|}{ 標淮偏差 } & 37.0 & 3.4 & 1573.5 & 675.8 & 29.4 & 4.5 & 230.9 & 15.3 & 26.5 & 8.5 & 152.8 & 78.1 \\
\hline \multicolumn{2}{|c|}{ 変動係数 } & 0.19 & 0.07 & 0.32 & 0.31 & 0.15 & 0.10 & 0.09 & 0.04 & 0.19 & 0.20 & 0.09 & 0.17 \\
\hline
\end{tabular}

先端部：曝露葉の黄化・褐変等の障害が認められた先端・周縁部及び未曝露葉の曝露葉と同様な部分の先端・周縁部, 残部：先端· 周縁部を除いた残りの部分

表 $21,500^{\circ} \mathrm{C}$ 発生装置から導入した木ウ素化合物の暴露試験による野菜の葉の木ウ素濃度と未暴露葉の木ウ素濃度

\begin{tabular}{|c|c|c|c|c|c|c|c|c|c|c|c|c|}
\hline \multirow{2}{*}{\multicolumn{2}{|c|}{ 野 菜 }} & \multirow{3}{*}{$\begin{array}{c}\text { 障害 } \\
\text { 発生日 }\end{array}$} & \multirow{3}{*}{$\begin{array}{l}\text { 曝露 } \\
\text { 日数 }\end{array}$} & \multirow{3}{*}{$\begin{array}{c}\text { 曝露 } \\
\text { 時間 } \\
\text { (h) }\end{array}$} & \multirow{2}{*}{\multicolumn{4}{|c|}{ ホウ素濃度 $(\mu \mathrm{g} / \mathrm{g})$}} & \multicolumn{2}{|c|}{ 先端部／残部 } & \multicolumn{2}{|c|}{ 懪露／未曝露 } \\
\hline & & & & & & & & & & & & \\
\hline 名 称 & 学 名 & & & & $\begin{array}{l}\text { 先端 } \\
\text { 部 }\end{array}$ & 残部 & $\begin{array}{l}\text { 先端 } \\
\text { 部 }\end{array}$ & 残部 & $\begin{array}{c}\text { 未曝 } \\
\text { 露 }\end{array}$ & 曝露 & $\begin{array}{l}\text { 先端 } \\
\text { 部 }\end{array}$ & 残部 \\
\hline イチゴ & Fragaria grandiffora & 7 & 14 & 143 & 230 & 37 & 1500 & 290 & 6.2 & 5.2 & 6.5 & 7.8 \\
\hline ハクサイ & Brassica campestris & 5 & 14 & 143 & 8.7 & 12 & 1500 & 110 & 0.7 & 14 & 170 & 9.2 \\
\hline ナンバ & Capsicum annuum & 19 & 50 & 478 & 210 & 63 & 2900 & 710 & 3.3 & 4.1 & 14 & 11 \\
\hline キャベツ & Brassica oleracea var capitata & 23 & 75 & 738 & 130 & 32 & 3800 & 550 & 4.1 & 6.9 & 29 & 17 \\
\hline \multicolumn{2}{|l|}{ 平均值 } & 14 & 38 & 376 & 150 & 36 & 2400 & 420 & 4.2 & 5.7 & 16 & 12 \\
\hline \multicolumn{2}{|l|}{ 最大值 } & 23 & 75 & 738 & 230 & 63 & 3800 & 710 & 6.2 & 14 & 170 & 17 \\
\hline \multicolumn{2}{|l|}{ 最小值 } & 5.0 & 14 & 143 & 8.7 & 12 & 1500 & 110 & 0.7 & 4.1 & 6.5 & 7.8 \\
\hline
\end{tabular}

·先端部 : 曝露葉の黄化·褐変等の障害が認められた先端・周縁部及び未曝露葉の曝露葉と同様な部分の先端・周縁部, 残部 : 先端· 周縁部を除いた残りの部分, 未曝露 : 未曝露葉, 曝露 : 曝露葉

樹木が被害を受けるかどうか検証した。

\section{1 野菜のガス状ホウ素化合物による人 工植物曝露試験}

各種野菜について $1,500^{\circ} \mathrm{C}$ ホウ素化合物 発生装置で発生した酸化ホウ素を主成分と したガス状ホウ素化合物による人工植物曝 露試駼結果を表 2 , 図 2 に, ホウ素曝露後 の各種野菜の葉の被害状況を写真 1 (50頁) に示す.

\subsection{1 黄化・褐变等の発生時期}

曝露系葉の先端・周縁部に扔いて, 黄 化・褐変等の発生時期や発生曝露日数か ら, ガス状ホウ素化合物の植物被害の速い 野菜の順は, (1)ハクサイ, (2)イチゴ, (3)ナ

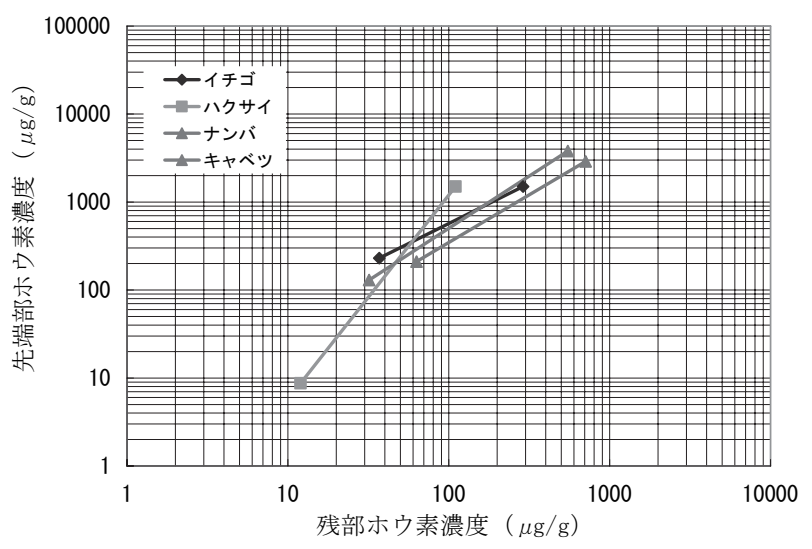

図 2 野菜の曝露系, 未曝露系別の先端部・残部の各木ウ素濃度 
ンバ，(4)キャベッであった。 ハクサイ，イチゴは 比較的早い時期から発生が見られたが, ナンバ, キャベツは発生が極めて遅く，耐性が比較的みら れる野菜であると考えられた。

\subsection{2 野菜の葉における含有木ウ素濃度}

各野菜の葉の曝露系の先端・周縁部含有ホウ素 濃度は $1,500 \sim 3,800 \mu \mathrm{g} / \mathrm{g}$, 平均が $2,400 \mu \mathrm{g} / \mathrm{g}$ であ り, 中央部含有ホウ素濃度は110 $710 \mu \mathrm{g} / \mathrm{g}$, 平 均が $420 \mu \mathrm{g} / \mathrm{g}$ であった. 未曝露系の先端・周縁部 含有ホウ素濃度は8.7 $230 \mu \mathrm{g} / \mathrm{g}$, 平均が $150 \mu \mathrm{g} / \mathrm{g}$ であり, 中央部含有ホウ素濃度は12 $63 \mu \mathrm{g} / \mathrm{g}$, 平 均が $36 \mu \mathrm{g} / \mathrm{g}$ であった，未曝露系に比べて曝露系 の野菜の葉の各含有ホウ素濃度は極めて高かった。

\subsection{3葉の先端・周緑部と見かけ上健全な葉の 色をしている中央部の濃度比}

各野菜の曝露系の葉の濃度比（(先端・周縁部 各含有ホウ素濃度) /(中央部各含有ホウ素濃度) ) は範囲が4.1 14倍，平均が5.7倍で，未曝露系は 範囲が 0.7 6.2倍，平均が4.2倍であった。各野菜 の濃度比は未曝露系でも曝露系と同様に高く,植 物はホウ素を取込んで成長する先端・周縁部へ輸 送する機能のあることを裏付けている。

\subsection{4 葉の先端・周縁部と中央部の濃縮割合}

野菜の葉の先端・周縁部の濃縮割合（曝露系各 含有ホウ素濃度 /未曝露系各含有ホウ素濃度) は, 範囲が6.5〜 170倍, 平均が16倍であり, 中央部は, 範囲が7.8〜17倍，平均が12倍であった，各野菜 の曝露葉の濃縮割合は，ほとんど先端・周縁部が 高かったが，イチゴは中央部がやや高かった。

\section{2 園芸植物のガス状ホウ素化合物による人工 植物曝露試験}

各種園芸植物について $1,500^{\circ} \mathrm{C}$ ホウ素化合物発 生装置で発生した酸化ホウ素を主成分としたガス 状ホウ素化合物による人工植物曝露試験結果を 表 3, 図 3(1)，(2)に，ホウ素曝露後の各種園芸 の葉の被害状況を写真2（51頁）に示す.

\subsection{1 黄化・褐変等の発生時期}

曝露系葉の先端・周縁部において, 黄化・褐変 等の発生時期や発生曝露日数から，ガス状ホウ素 化合物の植物被害の速い園芸植物の順は, (1)ガー ベラ, (2)ケイトウ, キンセンカ, (4)アスター, (5) ブルーサルビア，(6)キク，二チニチソウ，ストッ ク，チューリップ，(10)ゼラニウム，サルビア，プ
リムラ, パンジー, チェイランサス, (15)スイセン (16)八ボタン, シロタエギク, ディモールホセカ, (19)ナデシコ, シクラメン， (21)レディケイ， (22)トレ ニア,(23)ゴールドチャイルドであった. 比較的 3 日 〜25日と早いものから遅いものまで幅があった。

\subsection{2 各園芸植物の葉における含有木ウ素濃度}

各園芸植物の葉の曝露系の先端 - 周縁部含有木 ウ素濃度は760 8,200 $\mu \mathrm{g} / \mathrm{g}$, 平均が3,100 $\mu \mathrm{g} / \mathrm{g}$ であり,中央部含有ホウ素濃度は95 2,100 $\mu \mathrm{g} / \mathrm{g}$, 平均が500 $\mu \mathrm{g} / \mathrm{g}$ であった。 未曝露系の先端・周 縁部含有ホウ素濃度は5.8 $770 \mu \mathrm{g} / \mathrm{g}$, 平均が $170 \mu \mathrm{g} / \mathrm{g}$ であり, 中央部含有ホウ素濃度は12 $130 \mu \mathrm{g} / \mathrm{g}$, 平均が $40 \mu \mathrm{g} / \mathrm{g}$ であった。 未曝露系に 比べて曝露系の園芸植物の葉の各含有ホウ素濃度 は極めて高かった。

\subsection{3 葉の先端・周緑部と見かけ上健全な葉の 色をしている中央部の濃度比}

各園芸植物の曝露系の葉の濃度比（(先端・周 縁部各含有ホウ素濃度）／(中央部各含有ホウ素 濃度)）は範囲が1.9〜 69倍，平均が6.2倍で，未曝 露系は範囲が $0.2 〜 10$ 倍, 平均が4.3倍であった。 各園芸植物の濃度比は未曝露系でも曝露系と同様 に高く,植物はホウ素を取込んで成長する先端・周 縁部へ輸送する機能のあることを裏付けている.

\subsection{4 葉の先端・周縁部と中央部の濃縮割合}

各園芸植物の葉の先端・周縁部の濃縮割合（曝 露系各含有ホウ素濃度/未曝露系各含有ホウ素濃 度）は, 範囲が2.8〜330倍, 平均が18倍であり, 中央部は, 範囲が3.7〜43倍, 平均が13倍であった。 各園芸植物の曝露葉の濃縮割合は, ほとんど先 端・周縁部が高かったが，二チニチソウ，ガーベ ラ, ナデシコ, トレニア, シロタエギクは中央部 がやや高かった。

\section{3 樹木のガス状ホウ素化合物による人工植物 曝露試験}

各種樹木について $1,500^{\circ} \mathrm{C}$ ホウ素化合物発生装 置で発生した酸化ホウ素を主成分としたガス状ホ ウ素化合物による人工植物曝露試験結果を表 4 (52頁)，図４（52頁）に，ホウ素曝露後の各種樹 木の葉の被害状況を写真 3 (51頁) に示す.

\subsection{1 黄化・褐変等の発生時期}

曝露系葉の先端・周縁部において, 黄化・褐変 等の発生時期や発生曝露日数から, ガス状ホウ素 


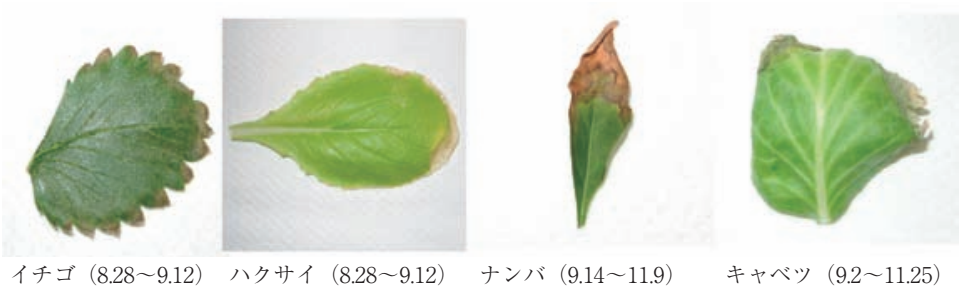

写真 1 ガス状ホウ素化合物による野菜の被害

表 $3 \quad 1,500^{\circ}$ C 発生装置から導入した木ウ素化合物の曝露試験による園芸植物の葉の木ウ素濃度と未曝露葉の木ウ素濃度

\begin{tabular}{|c|c|c|c|c|c|c|c|c|c|c|c|c|}
\hline \multirow{2}{*}{\multicolumn{2}{|c|}{ 園芸植物 }} & \multirow{3}{*}{$\begin{array}{c}\text { 障害 } \\
\text { 発生日 }\end{array}$} & \multirow{3}{*}{$\begin{array}{l}\text { 曝露 } \\
\text { 日数 }\end{array}$} & \multirow{3}{*}{$\begin{array}{c}\text { 曝露 } \\
\text { 時間 } \\
\text { (h) }\end{array}$} & \multicolumn{4}{|c|}{ ホウ素濃度 $(\mu \mathrm{g} / \mathrm{g})$} & \multirow{2}{*}{\multicolumn{2}{|c|}{ 先端部／残部 }} & \multirow{2}{*}{\multicolumn{2}{|c|}{ 曝露 /未儤露 }} \\
\hline & & & & & \multicolumn{2}{|c|}{ 末曝露 (対照) } & \multicolumn{2}{|c|}{ 曝 露 } & & & & \\
\hline 名 称 & 学 名 & & & & $\begin{array}{l}\text { 先端 } \\
\text { 部 }\end{array}$ & 残部 & $\begin{array}{c}\text { 先端 } \\
\text { 部 }\end{array}$ & 残部 & 末儤露 & 樭露 & 先端部 & 残部 \\
\hline キク & Chrysanthemum morifolium & 10 & 22 & 221 & 88 & 20 & 1400 & 110 & 4.4 & 13 & 16 & 5.5 \\
\hline ニチニチソウ & Catharanthus raseus & 10 & 22 & 221 & 190 & 19 & 2500 & 340 & 10 & 7.4 & 13 & 18 \\
\hline ゼラニウム & Pelargonium hortorum & 11 & 22 & 221 & 74 & 40 & 1000 & 520 & 1.9 & 1.9 & 14 & 13 \\
\hline ガーベラ & Gerbera Hybrids & 3 & 15 & 171 & 96 & 12 & 1200 & 200 & 8.0 & 6.0 & 13 & 17 \\
\hline ナデシュ & Dianthus hybridus & 17 & $4 \mathrm{I}$ & 400 & 270 & 63 & 760 & 260 & 4.3 & 2.9 & 2.8 & 4.1 \\
\hline サルビア & Salvia splendens & 11 & 41 & 400 & 82 & 31 & 2800 & 710 & 2.6 & 3.9 & 34 & 23 \\
\hline トレニア & Torenia foumieri & 24 & 41 & 400 & 770 & 77 & 2400 & 750 & 10 & 3.2 & \begin{tabular}{l|l}
3.1 & 0 \\
\end{tabular} & 9.7 \\
\hline ブルーサルビア & Salvia farinacea & 7 & 50 & 478 & 120 & 43 & 3500 & 520 & 2.8 & 6.7 & 29 & 12 \\
\hline ケイトウ & Celosia cristata & 4 & 16 & 159 & 150 & 40 & 2000 & 180 & 3.8 & 11 & 13 & 4.5 \\
\hline プリムラ & Primula polyantha & 11 & 16 & 159 & 140 & 22 & 3500 & 330 & 6.4 & 11 & 25 & 15 \\
\hline パンジー & Viola tricolor var hortensis & 11 & 16 & 159 & 51 & 27 & 3800 & 340 & 1.9 & 11 & 75 & 13 \\
\hline アスター & Callistephus chinensis & 6 & 11 & 107 & 120 & 30 & 1300 & 460 & 4.0 & 2.8 & 11 & 15 \\
\hline ハボタン & Brassica oleracea var. acephala & 15 & 19 & 185 & 75 & 17 & 7800 & 430 & 4.4 & 18 & 100 & 25 \\
\hline シクラメン & Cyclamen persicum & 17 & 19 & 185 & 200 & 73 & 910 & 290 & 2.7 & 3.1 & \begin{tabular}{l|l}
4.6 \\
\end{tabular} & 4.0 \\
\hline キンセンカ & Calendula officinalis & 4 & 19 & 185 & 490 & 130 & 8200 & 1100 & 3.8 & 7.5 & 17 & 8.5 \\
\hline ストック(Av) & Matthiola incana & 10 & 13 & 126 & 66 & 29 & 1700 & 180 & 2.3 & 9.4 & 26 & 6.2 \\
\hline シロタエギク(Av) & Centaurea cineraria & 15 & 25 & 243 & 194 & 49 & 5000 & 2100 & 4.0 & 2.4 & 26 & 43 \\
\hline チェイランサス(AV) & Erysimum cheiri & 11 & 21 & 213 & 190 & 46 & 2500 & 350 & 4.1 & 7.1 & 13 & 7.6 \\
\hline スイセン & Narcissus tazetta var. chinensis & 13 & 37 & 361 & 240 & 26 & 6600 & 95 & 9.2 & 69 & 28 & 3.7 \\
\hline ディモールホセカ & Dimorphotheca & 15 & 22 & 205 & 120 & 40 & 4000 & 980 & 3.0 & 4.1 & 33 & 25 \\
\hline チューリップ & Tulipa gesneriana & 10 & 22 & 205 & 120 & 26 & 4900 & 200 & 4.6 & 25 & 41 & 7.7 \\
\hline ゴールドチャイルド & Hedera helix & 25 & 29 & 270 & 5.8 & 31 & 1900 & 510 & 0.2 & 3.7 & 330 & 16 \\
\hline レディケイ & Hedera helix & 22 & 29 & 270 & 41 & 26 & 2700 & 420 & 1.6 & 6.4 & 66 & 16 \\
\hline \multicolumn{2}{|l|}{ 平均值 } & 12 & 25 & 241 & 170 & 40 & 3100 & 500 & 4.3 & 6.2 & 18 & 13 \\
\hline \multirow{2}{*}{\multicolumn{2}{|c|}{$\begin{array}{l}\text { 最大值 } \\
\text { 最小优 }\end{array}$}} & 25 & 50 & 478 & 770 & 130 & 8200 & 2100 & 10 & 69 & 330 & 43 \\
\hline & & 3.0 & 11 & 107 & 5.8 & 12 & 760 & 95 & 0.2 & 1.9 & 2.8 & 3.7 \\
\hline
\end{tabular}

·先端部 : 曝露葉の黄化・褐変等の障害が認められた先端・周縁部及び未曝露葉の曝露葉と同様な部分の先端・周縁部, 残部 : 先端 · 周縁部を除いた残りの部分, 未曝露: 未曝露葉, 曝露：曝露葉.

(1)

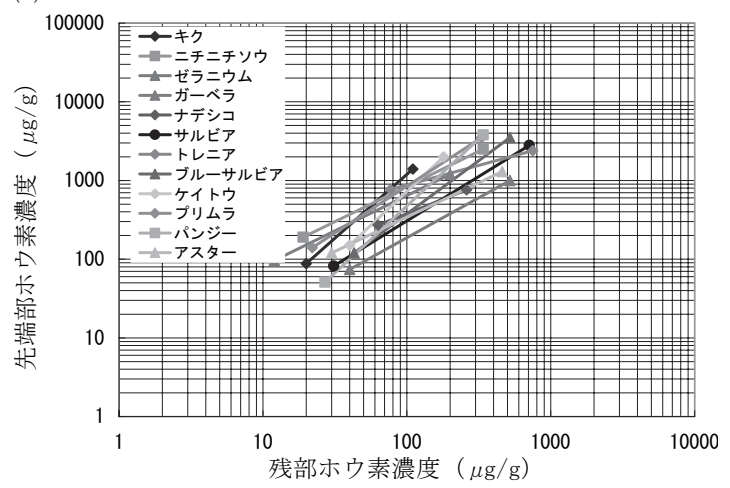

(2)

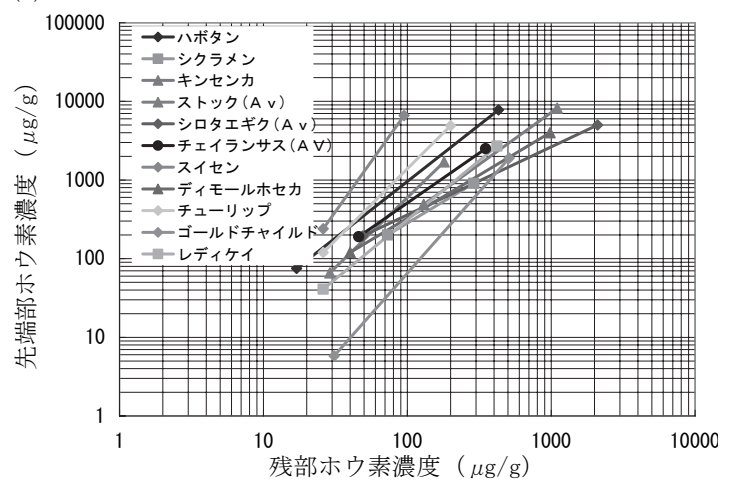

図 3 園芸植物の曝露系, 未曝露系別の先端部・残部の各木ウ素濃度 


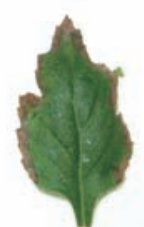

キク $(8.28 \sim 11.20)$

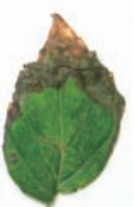

サルビア $(9.23 \sim 11.9)$

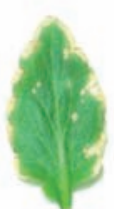

パンジー（11.9〜11.25）
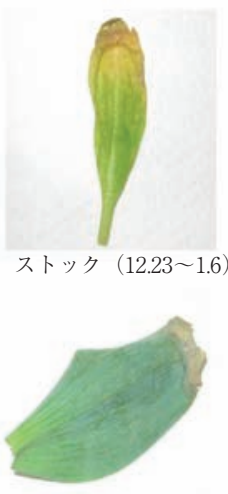

チューリップ

$(3.13 \sim 4.4)$

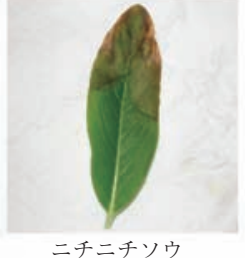

(8.28 11.20)

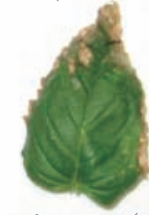

トレニア $(9.23 \sim 11.9)$ ブルーサルビア

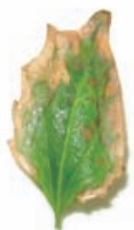

スター $(11.25 \sim 128)$

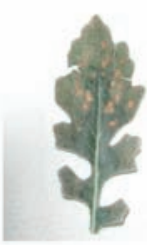

シロタエギク（11.9～213） チェイランサス

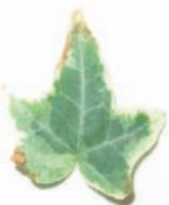

$$
\text { ゴールドチヤイルド }
$$

(3.13 4.11)
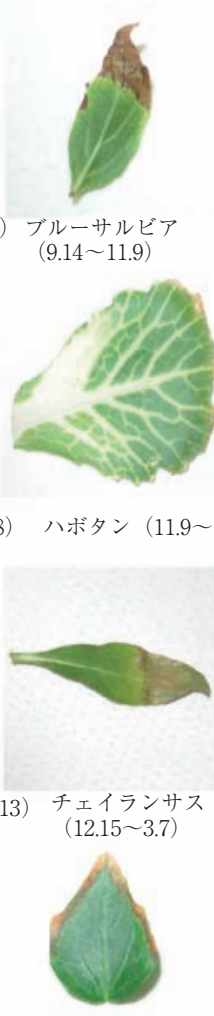

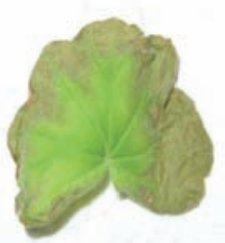

ゼラニウム $(8.28 \sim 11.20)$

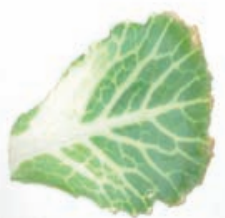

ハボタン $(11.9$ 12.16)

レディケイ $(3.13 \sim 4.11)$

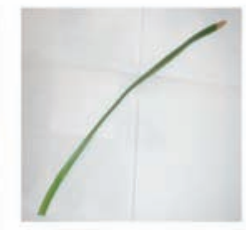

スイセン $(1.29 \sim 3.7)$

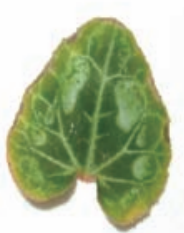

写真2 ガス状ホウ素化合物による園芸植物の被害
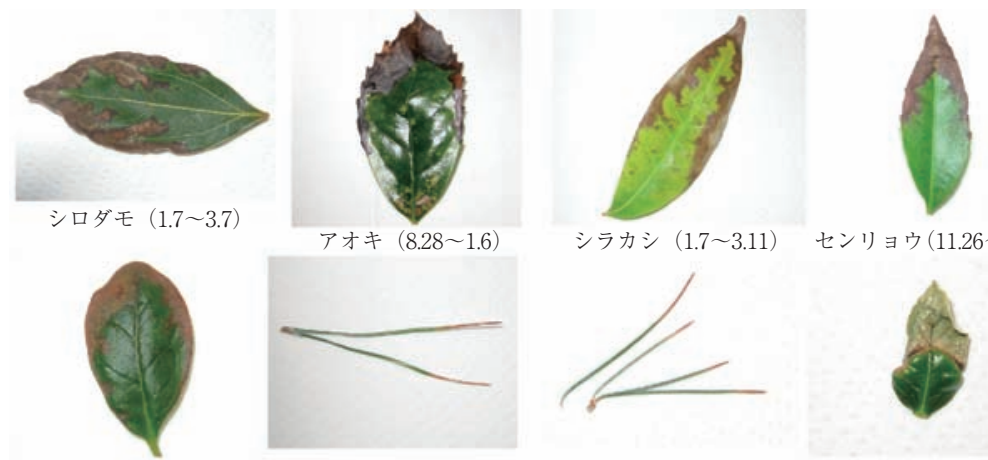

コニファ $(9.14 \sim 3.7$
シクラメン (11.26〜12.16)

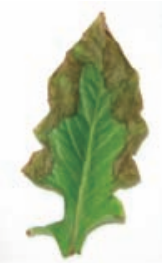

ガーベラ
$(9.2 \sim 11.20)$

ナデシコ $(9.23 \sim 11.9)$

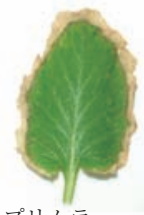

プリムラ

$(11.9 \sim 11.25)$

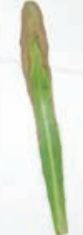

キンセンカ $(11.26$ 12.16)

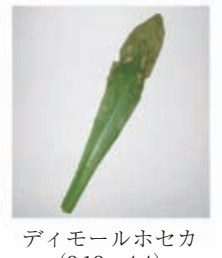

(3.13 4.4)

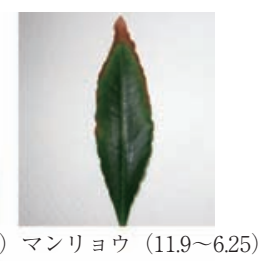


表 $4 \quad 1,500^{\circ} \mathrm{C}$ 発生装置から導入した木ウ素化合物の曝露試験による樹木の葉の木ウ素濃度と未曝露葉の木ウ素濃度

\begin{tabular}{|c|c|c|c|c|c|c|c|c|c|c|c|c|}
\hline \multirow{2}{*}{\multicolumn{2}{|c|}{ 樹 木 }} & \multirow{3}{*}{$\begin{array}{c}\text { 障害 } \\
\text { 発生日 }\end{array}$} & \multirow{3}{*}{$\begin{array}{l}\text { 曝露 } \\
\text { 日数 }\end{array}$} & \multirow{3}{*}{$\begin{array}{c}\text { 曝露 } \\
\text { (h) }\end{array}$} & \multicolumn{4}{|c|}{ ホウ素濃度 ( $\mu \mathrm{g} / \mathrm{g}$ ) } & \multirow{2}{*}{\multicolumn{2}{|c|}{ 先端部／残部 }} & \multirow{2}{*}{\multicolumn{2}{|c|}{ 曝露／未曝露 }} \\
\hline & & & & & \multicolumn{2}{|c|}{ 末曝露 (対照) } & \multicolumn{2}{|c|}{ 曝 露 } & & & & \\
\hline 名 称 & 学 名 & & & & 先端部 & 残部 & 先端部 & 残部 & 末㩧露 & 曝露 & 先端部 & 残部 \\
\hline シロダモ(Av) & Neolitsea sericea & 8 & 56 & 547 & 140 & 43 & 1600 & 470 & 3.3 & 3.4 & 11 & 11 \\
\hline アオキ & Aucuba japonica & 58 & 117 & 1149 & 130 & 60 & 1200 & 160 & 0.5 & 7.5 & 20 & 1.2 \\
\hline シラカシ(Av) & Quercus myrsinaefolia & 22 & 112 & 1071 & 230 & 140 & 1500 & 860 & 1.6 & 1.7 & 6.5 & 6.1 \\
\hline センリョウ & Chloranthus glaber & 20 & 56 & 545 & 78 & 36 & 2600 & 510 & 2.2 & 5.1 & 33 & 14 \\
\hline マンリョウ & Ardisia crenata & 21 & 72 & 704 & 77 & 16 & 3100 & 860 & 4.8 & 3.6 & 40 & 54 \\
\hline アザレア & Rhadodendron & 11 & 44 & 429 & 190 & 41 & 1900 & 200 & 4.6 & 9.5 & 10 & 4.9 \\
\hline クロマツ & Pinus thunbergü Parlatore & 85 & 167 & 1543 & 98 & 11 & 1300 & 130 & 8.9 & 10 & 13 & 12 \\
\hline$\Xi ニ フ ァ$ & Cedrus deadara & 95 & 167 & 1543 & 130 & 18 & 1700 & 490 & 7.2 & 3.5 & 13 & 27 \\
\hline クチナシ & Gardenia jasminoides Ellis & 34 & 64 & 614 & 87 & 55 & 1900 & 960 & 1.6 & 2.0 & 22 & 17 \\
\hline サザンカ & Camellia sasanqua & 22 & 29 & 270 & 170 & 65 & 2300 & 850 & 2.6 & 2.7 & 14 & 13 \\
\hline \multicolumn{2}{|l|}{ 苹均值 } & 38 & 88 & 842 & 130 & 56 & 1900 & 550 & 2.3 & 3.5 & 15 & 10 \\
\hline \multicolumn{2}{|l|}{ 最大值 } & 95 & 167 & 1543 & 230 & 140 & 3100 & 960 & 8.9 & 10 & 40 & 54 \\
\hline \multicolumn{2}{|l|}{ 最小㥀 } & 8.0 & 29 & 270 & 60 & 11 & 1200 & 130 & 0.5 & 1.7 & 6.5 & 1.2 \\
\hline
\end{tabular}

先端部：曝露葉の黄化・褐変等の障害が認められた先端・周縁部及び未曝露葉の曝露葉と同様な部分の先端・周縁部, 残部 : 先端 $・$ 周縁部を除いた残りの部分, 未曝露：未曝露葉，曝露：曝露葉

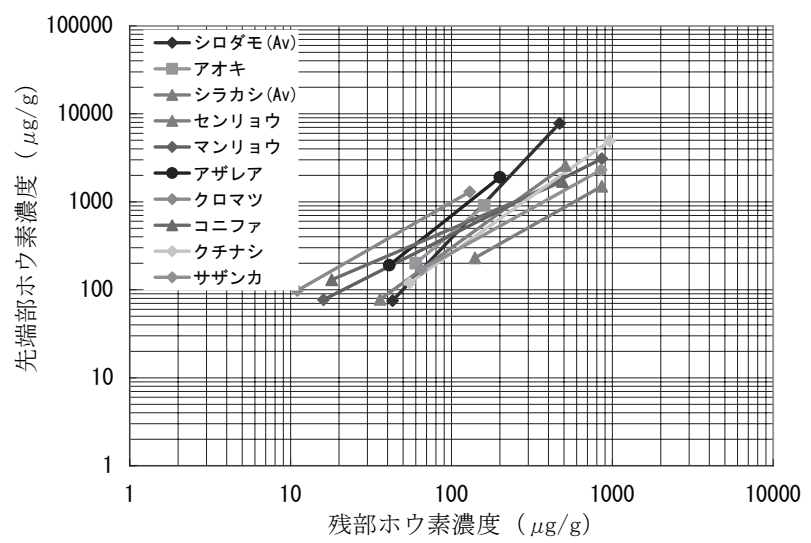

図 4 樹木の曝露系，未曝露系別の先端部・残部の各木ウ素濃度
めて高かった.

\subsection{3葉の先端·周緑部と見かけ上健全な 葉の色をしている中央部の濃度比}

各樹木の曝露系の葉の濃度比（(先端・ 周縁部各含有ホウ素濃度）／（中央部各含 有ホウ素濃度)）は範囲が1.7 10倍，平均 が3.5倍で, 未曝露系は範囲が0.5〜8.9倍, 平均が2.3倍であった。各樹木の濃度比は 未曝露系でも曝露系と同様に高く, 植物は ホウ素を取込んで成長する先端・周縁部へ 輸送する機能のあることを裏付けている。

\subsection{4 葉の先端・周縁部と中央部の濃縮 割合}

化合物の植物被害の速い樹木の順は, (1)シロダモ, (2)アザレア，(3)センリョウ，(4)マンリョウ，(5)サ ザンカ, シラカシ, (7)クチナシ, (8)アオキ, (9)ク ロマツ, (10)コニファであった. 8 日〜95日で早い ものから遅いものまで幅があった。

\subsection{2 各樹木植物の葉における含有木ウ素濃度}

各樹木の葉の曝露系の先端 ・ 周縁部含有ホウ素 濃度は $1,200 \sim 3,100 \mu \mathrm{g} / \mathrm{g}$, 平均が $1,900 \mu \mathrm{g} / \mathrm{g}$ であ り，中央部含有ホウ素濃度は130 $960 \mu \mathrm{g} / \mathrm{g}$, 平 均が550 $\mu \mathrm{g} / \mathrm{g}$ であった。 未曝露系の先端・周縁 部含有ホウ素濃度は60 230 $\mu \mathrm{g} / \mathrm{g}$, 平均が $130 \mu \mathrm{g} / \mathrm{g}$ であり, 中央部含有ホウ素濃度は11〜 $140 \mu \mathrm{g} / \mathrm{g}$, 平均が56 $\mu \mathrm{g} / \mathrm{g}$ であった。 未曝露系に 比べて曝露系の樹木の葉の各含有ホウ素濃度は極
各樹木の葉の先端・周縁部の濃縮割合（曝露系 各含有ホウ素濃度／未曝露系各含有ホウ素濃度） は，範囲が6.5〜40倍，平均が15倍であり，中央 部は範囲が1.2〜 54倍, 平均が10倍であった。各 樹木の曝露葉の濃縮割合は，ほとんど先端・周縁 部が高かったが, シロダモ, マンリョウ, コニファ は同等か中央部がやや高かった。

\section{4 植物被害の全体の状況}

植物被害を発生させた工場とほほ同じ $1,500^{\circ} \mathrm{C}$ でガス状ホウ素化合物を発生させ，人工植物曝露 試験を行い, 各種野菜, 園芸植物及び樹木が被害 を受けるかどうか検証した。その結果，葉の先端 部等に黄化・褐変等の障害が認められ，過去の植 物被害がほぼ再現された。 
各種野菜，園芸植物及び樹木の被害状況は，葉 の先端部等に黄化・褐変等の障害が認められた. これは過去に発生した問題の工場周辺の植物被害 状況 $^{7)}$ 及び既報 ${ }^{8,12)}$ の $60 \sim 90^{\circ} \mathrm{C}$ でホウ素化合物を 発生させた人工植物曝露被害状況8, 12) とほぼ同じ 障害であった。

今回の $1,500^{\circ} \mathrm{C}$ で酸化ホウ素ガスを主成分とし た曝露試験，前回の $60 \sim 90^{\circ} \mathrm{C}$ のホウ酸ガスを主成 分とした曝露試験，過去に発生した植物被害の状 況がほぼ同じであったことから，これらのデータ では原因物質は特定できないがホウ酸ガスが一番 疑わしいことが考えられる。

\section{4. まとめ}

植物被害を発生させた工場とほぼ同じ $1,500^{\circ} \mathrm{C}$ でガス状ホウ素化合物を発生させ，人工植物曝露 試験を行い，各種野菜，園芸植物及び樹木が被害 を受けるかどうか検証した。その結果，葉の先端 部等に黄化・褐変等の障害が認められ, 過去の植 物被害がほぼ再現された。

(1)曝露試験に用いた野菜はイチゴなど 4 種類，園 芸植物はキクなど 23 種類, 樹木はシロダモなど 10 種類であった，各植物の曝露系の葉の先端・ 周縁部の含有ホウ素濃度は760～8,200 $\mu \mathrm{g} / \mathrm{g}$ で, 残り中央部は95 2,100 $\mu \mathrm{g} / \mathrm{g}$ であった。未曝 露系に比べて曝露系の葉の各含有ホウ素濃度は 極めて高かった。

(2)葉の濃度比でみると曝露系の先端・周縁部は中 央部に比べて1.7〜 69倍高く，植物がホウ素を 取込んで成長する先端・周縁部へ輸送する機能 のあることを裏付けている。

(3)葉の部分別の曝露濃縮割合（曝露系各含有ホウ 素濃度／未曝露系各含有ホウ素濃度) は, 先端・ 周縁部は2.8～330倍で，中央部1.2〜 54倍で，先 端・周縁部の濃縮割合は高かった。

(4)今回の $1,500^{\circ} \mathrm{C}$ で酸化ホウ素ガスを主成分とし た曝露試験，前回の $60 \sim 90^{\circ} \mathrm{C}$ のホウ酸ガスを主 成分とした曝露試験，過去に発生した植物被害 の状況がほぼ同じであったことから、これらの
データでは原因物質は特定できないがホウ酸ガ スが一番疑わしく，植物体内で作用するメカニ ズムがほぼ同じであると推定される。

（本稿は，平成15 17年度環境省地球環境保全等試 験研究費地域密着型研究「ガス状ほう素化合物によ る大気污染監視測定技術及び除外技術の開発」によ る研究成果の一部である.)

\section{文献}

1 ）環境省；大気污染物質のレビュー IC 産業関連物質 IV ホ ウ素及びホウ素化合物，東京，pp.90-113，1987.

2 ) IPCS Environmental Health Criteria 204 Boron, WHO, Geneva, 1998

3 ) Chiwon, W.L., Jong-Myung, C. ,Chun-Ho, P. ; Micronutrient Toxicity in Seed Geranium. J. Amer. Soc. Hort. Sci., 121, 77-82,1996.

4 ) Anderson, D.L.,Kitto, M.E.,McCarthy, L., Zoller H.Z. ; Sources and Atmospheric Distribution of Particulate and Gas-phase Boron. Atmos. Environ., 28, 1401-1410,1994.

5 ) 渡辺和彦; 原色生理障害の診断法, 農山漁村文化協会, 東京, pp132-133, pp172-175,1986.

6 ）高橋英一; 比較植物栄養学, 養賢堂, 東京, 86-97, 1974.

7 ) 鳥山成一, 安田 洋, 島田和保, 水上昭弘, 大西勝典, 近 藤隆之, 神保高之, 橋本俊一, 西川雅高, 吉永 淳, 田中 敦；ガス状ホウ素化合物による大気污染について, 環境 化学, 13, 409-416,2003.

8 ) 鳥山成一, 近藤隆之, 水畑剛, 奥村秀一, 水上昭弘, 神 保高之, 山嵪敬久, 木戸瑞佳, 日吉真一郎, 溝口俊明, 吉永 淳, 安田洋, 田中敦, 西川雅高, 吉永 淳, 田尾博 明；人工植物曝露装置を用いたガス状ホウ素化合物によ るゼラニウムの被害の検証，環境化学，14, 825-834, 2004.

9 ) 鳥山成一, 近藤隆之, 奥村秀一, 水上昭弘, 山崎敬久, 木戸瑞佳, 日吉真一郎, 溝口俊明, 田中敦, 西川雅高 ; 大気中のホウ素化合物の工場発生源排出濃度及び周辺環 境濃度測定方法の検討, Journal of ecotechnology research, 11, 23-27,2005

10) DIBORANE 6006, NIOSH Manual of Analytical Methods (NMAM), Fourth Edition, 8/15/94.

11）渡辺和彦；原色生理障害の診断法，農山漁村文化協会， 東京, pp.21, 1986

12）鳥山成一，近藤隆之，奥村秀一，水上昭弘，山㠃敬久， 木戸瑞佳, 日吉真一郎, 溝口俊明, 安田 洋, 田中 敦, 西川雅高, 吉永 淳, 田尾博明; 人工植物曝露装置を用い たガス状ホウ素化合物による各種野菜，園芸植物及び樹 木の黄化・褐変等の障害, 環境化学, 15, 761-770, 2005.

13）昭和46年12月 28 日環境庁告示 59 ；付表 7 ，「水質污濁に 係る環境基準について」.

14）環境庁大気保全局大気規制課監修; 有害大気污染物質測 定の実際，(財日本環境衛生センター, 1997 